\title{
EFFECTIVENESS OF LOWER LEG COMPRESSION MANEUVER IN \\ REDUCING SPINAL ANESTHESIA INDUCED HYPOTENSION \\ FOR WOMEN UNDERGOING CESAREAN SECTION
}

\author{
Inaam Hassan Abd Elati', Mohamed Nezar Elshahat' ${ }^{2}$,Maha Ramadan Ali ${ }^{3}$, \\ Aya Hamdino Mohamed Rashad ${ }^{4}$
}

\begin{abstract}
Assistant Professor of Maternal ,Obstetrics and gynecology Nursing Faculty of Nursing - Port Said University Egypt ${ }^{1}$, Professor of medical obstetrics and gynecology faculty of medicineMansoura university Egypt ${ }^{2}$, Lecturer of Maternal ,Obstetrics and gynecology Nursing Faculty of Nursing - Port Said University ${ }^{3}$
\end{abstract}

\begin{abstract}
Background: Hypotension during spinal anesthesia for caesarean delivery remains a common clinical problem. It has a risk factor for adverse maternal and fetal events. This study aimed to evaluate the effectiveness of lower leg compression maneuver in reducing spinal anathesia induced hypotension for women undergoing cesarean Section. A Quasi-experimental design was utilized in the current study. Setting: The study was conducted at cesarean delivery unit in Mansoura University Hospital during the period from October 2016 to March 2017. $A$ systematic random sample was calculated to be 220 of women underwent elective cesarean delivery with spinal anesthesia to be recruited in both study group and control group. Prehydration and anesthetic technique standardized protocol was followed. Hypotension defined as a decrease in any mean arterial pressure (MAP) measurement by more than $20 \%$ of the baseline. Tools: Three tools were used in the current study to collect the necessary data, Structured interviewing questionnaire sheet, maternal hemodynamic and signs of hypotension record, and neonatal assessment sheet. Results: A highly statistical significant difference was found between study group and control group regarding mean arterial pressure and neonatal acidosis .Conclusion: lower leg compression for women under elective cesarean with spinal anesthesia is more effective measure to reduce spinal anathesia induced hypotension during cesarean delivery. Recommendations: lower leg compression during cesarean delivery should be included in maternal hospitals protocol for reducing spinal induced hypotension during cesarean delivery.
\end{abstract}

Keywords: Lower Leg Compression, Hypotension, Cesarean Delivery, Spinal anathesia induced Hypotension, and Nursing care. 


\section{INTRODUCTION}

Cesarean section (CS) is a life-saving surgical procedure when certain complications arise during pregnancy and labor. However, it is a major surgery and is associated with immediate maternal and perinatal risks and may have implications for future pregnancies as well as long term effects that are still being investigated (Betrán et al., 2016).The incidence of C-sections has increased significantly in Egypt. It is estimated that a C-section is carrying one of every six births today in Egypt out. this dramatic increase raises several concerns of medical, ethical and economic importance (Awadalla, 2016). WHO stated that the caesarean section (CS) rate in Egypt was 27.6\% in the year 2010. According Ministry of Health and Populations reported data; more than $50 \%(50.8 \%)$ of all deliveries were by CS without much difference between urban and rural areas (Ministry of Health and Populations 2015; Dawood et al., (2017).

Spinal anesthesia is the popular route of anesthesia in parturient for cesarean delivery. Spinal anesthesia is not free from side effects and has its own complications like maternal hypotension, fetal cardiac decelerations, post-operative headache and patients at risk of heavy peripartum hemorrhage may not tolerate the hemodynamic effects of regional anesthesia (Habib, Ituk, \& Cooter, 2016; Awadalla A (2016).Maternal hypotension is a common complication after spinal anesthesia resulting in adverse maternal and fetal outcomes. There is a high incidence of post spinal hypotension (50-80\%) in patients having caesarean sections. Maternal side effects of hypotension include nausea, vomiting and cardiovascular collapse. Neonatal side effects of hypotension may include acidosis and depression. (Butwick, Columb, \&Carvalho2015).

The basic components of management of PSH are Fluid loading, Pharmacological agents and positioning protocols. (Butwick, Columb \&Carvalho2015).Most of the positioning protocols have one of the two following targets: (1) Relieving aortocaval compression. (2) Increasing venous return. The use of leg compression is effective in the prevention of post spinal hypotension in cesarean patients. (Cluver, Novikova, Hofmeyr, Hall2013).Mechanical compression of legs is a simple technique and found to be comparable with use of vasopressors in the prevention of post spinal hypotension in cesarean patients. It is being a simple, nonpharmacological and cost-effective technique can be used on a daily basis to prevent hypotension. (Sujata N, Arora D, Panigrahi BP, Hanjoora VM 2012).

Nurse's role is crucial in preventing complications and assessing patient needs at the hospital because she stays with the patient 24 hours per day, that is why she should have sound 
knowledge of medical management and nursing care during the peri, intra and postoperative period of women undergoing cesarean section. Since the major function of the nurse is to provide the care required for the prevention, promotion of health, and the prevention of postoperative complications, (Malani 2005).

\section{The significance of the study:}

Although CS is necessary to save the life of the baby or mother, it carries more risk to both the mother and the baby. The incidence of hypotension during spinal anesthesia for Caesarean section is reported to be as high as $80 \%$. So, Preventing hypotension during spinal anesthesia for the cesarean section has been referred as "Holy Grail " in obstetric (Khedr, 2011;Butwick, Columb \&Carvalho2015). Therefore, this study was conducted to evaluate the effectiveness of lower leg compression maneuver in reducing spinal induced hypotension for women undergoing Cesarean Section.).

\section{AIM OF STUDY:}

The aim of the study was to evaluate the effectiveness of lower leg compression maneuver in reducing spinal induced hypotension for women undergoing Cesarean Section.

Research Hypothesis:_Applying lower leg compression during cesarean delivery reduces maternal hypotension .

\section{SUBJECT AND METHOD:}

\section{Research design:}

This study was carried out by using a quasi-experimental research design.

\section{Setting}

The present study was carried out at the cesarean delivery operating room at obstetrical and gynecological department affiliated to Mansoura University Hospital.

\section{Study Population and Sample:}

The target population consists of nulliparous and multiparous women, as each woman who had an odd number at cesarean operational delivery list was recruited in the present study.Sampling method: A simple random sample technique was used to select the women under the study during the study period.

Sampling and Sample size: The sample size was determined by using the following equation (Brown \& Hollander, 1977): 


\section{Sample size $(\mathbf{n})=\quad P(1-P)$}

D2

P : $\quad$ Proportion of spinal induced hypotension $=40 \%$

$\mathbf{Z}$ : a percentile of standard normal distribution determined by $95 \%$ confidence level $=$ 1.96

D : $\quad$ One half the width of the desired sample confidence interval $=5 \%$

The calculated sample size is $\mathbf{2 0 0}$ women. Due to the expected non-participating rate $(10 \%)$, the final sample size was $\mathbf{2 2 0}$ women divided into two groups as control and intervention 110 women for each group.

\section{Inclusion criteria:}

1. The pregnant women whose Age ranged from 20 to 35 years old.

2. Elective cesarean delivery.

3 .Single fetus.

4 .Free from any pregnancy related complications.

5 .Gestational age $\geq 37$ wks.

6 . Height between $130 \mathrm{~cm}$ and $180 \mathrm{~cm}$.

\section{Exclusion criteria}

1. Women with history of deep venous thrombosis of

Their lower limbs.

2. Women with superficial thrombophlebitis of their legs.

3. Women with allergic reaction developed to the local Anesthetic before.

4. Morbid obese women with body mass index more than $30 \mathrm{~kg} / \mathrm{m}$.

\section{TOOLS FOR DATA COLLECTION:}

\section{Interviewing questionnaire form (Appendix I)}

The questionnaire was designed for the study's objectives and consisted of different questions /phrases in two parts including:

- Part 1: Woman's socio-demographic data such as age, level of education, job status, income, and residence.

- Part 2: An obstetrical history which includes; gravidity, parity, weeks of gestation.

Maternal hemodynamic and signs of hypotension record (Appendix II ) was administered to members of the two groups. 


\section{Neonatal outcomes assessment sheet (Appendix III)}

Assessment of the umbilical arterial blood $\mathrm{PH}$, umbilical venous blood $\mathrm{PH}$, and Apgar score at 1 st and 5 th minutes.

\section{Tools validity:}

It was ascertained by a jury consisting of five experts in nursing field.

\section{Reliability:}

Cronbach's alpha coefficient was calculated to assess the reliability of the developed tool through their internal consistency.

\section{Administrative design.}

An official permission was granted by submission of an official letter from the Faculty of Nursing to the responsible authorities of the study setting to obtain their permission for data collection. Nursing and medical staff responsible for the patient were approached to gain their cooperation.

\section{Ethical consideration}

All ethical issues were taken into consideration during all phases of the study; the researcher maintained an anonymity and confidentiality of the subjects. The researcher introduced herself to the women and briefly explained the nature and aim of the study to every woman before participation and obtained an oral consent from her. Women were assured that the information obtained during the study was confidential and used for the research purpose only.

\section{Operational design}

This includes the preparatory phase, pilot study, and the intervention.

\section{Preparatory phase}

The researcher, after an extensive review of the literature, prepared the tools for data collection. Then, the tools were tested for their content validity through the opinions of experts. These included 5 experts in the field of obstetrics and gynecology from medical and nursing faculty staff whose opinions were thought using an opinion sheet. Thus sheet involved two parts: (1) the opinions of the expert for each item regarding its relevance and clarity; (2) general 
or overall opinion about the form. They were requested to express their opinions and comments on the tool and provide any suggestions for any additional or omissions of items.

Then necessary modifications were done. This phase was carried out in a period of two months. Reliability was done by Cronbach's Alpha Coefficient Test which revealed that each item of the utilized tools consisted relatively homogeneous items.

\section{Pilot study :}

A pilot study was carried out on 20 women who match with eligibility criteria in order to test the applicability of the tools, clarity and simplicity of the included questions as well as to estimate the average time needed to complete the sheets. Those who shared in the pilot study were excluded from the main study sample. Necessary modifications were carried out based on the finding of the pilot study to develop the final form of the tools.

\section{Intervention phase:}

Following this pilot study, the process of data collection consumed 6 months from October 2016 to March 2017. The data were collected according to the following phases:

\section{Baseline assessment phase:}

During this phase, the process of sampling was done. Women fulfilling the eligibility criteria were invited to participate. The data were collected from the pregnant women who gave their oral consent all mothers signed an informed consent after full explanation of spinal anesthesia with respect to lumbar spinal puncture, the local anesthetic used in this study, and the possible complications that could occur during the study.

\section{Implementation phase:}

All of the intervention was administered to women of both groups were conducted by the researcher who had adequate experience in the field of operative care and full understanding of this technique. At the beginning of the pre-operative, a question and answer session was conducted for the initial survey of the women's knowledge, this was followed by Physical assessment; pregnant women's vital signs.

All mothers received $500 \mathrm{ml}$ of lactated ringer solution as preloading fluid, and then all the patients received spinal anesthesia at levels between L3-L4 or L4-L5 interspaces. All mothers were cumulated in the left antecubital vein with $16 \mathrm{G}$ intravenous catheters (cannula), and 
monitored by noninvasive blood pressure, pulse oximeter, and electrocardiography .While in the sitting position giving hyperbaric bupivacaine $0.5 \% 2.5 \mathrm{ml}(12.5 \mathrm{mg})$, and then the mothers were put in the supine position with a 15o-30o left lateral tilt just after receiving the anesthesia. For the leg compression group compression knee stockings were applied, a thigh-length gradient compression stocking was used, the compression pressure level was between 15 and $20 \mathrm{mmHg}$. The compression knee stockings were applied until the end of cesarean delivery.

The both groups had the routine nursing care.

\section{Evaluation phase:}

Evaluation of women for both study and control group the following hemodynamic measures including systolic arterial pressure, diastolic arterial pressure and mean arterial pressure (SAP,DAP, MAP) were recorded at baseline and after spinal anesthesia until the end of cesarean delivery. The baseline hemodynamic variables measures were defined as the average of three consecutive recordings with less than $10.0 \%$ variation over 10 mins before prehydration

\section{STATISTICAL DESIGN}

After collection of data, it was revised, coded, and fed to statistical software SPSS version 16 . The statistical analysis used $\mathrm{T}$ test with alpha error $=0.05$. Microsoft office excels software was used to construct the needed graphs. After data coding, the following data manipulations were done.

\section{Data analysis:}

After data manipulation was done all numeric data were expressed in the form of range (minimum to maximum), mean and standard deviation (SD). Categorical data were expressed in the form of frequencies and percentages.

\section{A. Analysis of numeric data:}

One-Sample Kolmogorov-Smirnov Test: a procedure compares the observed cumulative distribution function for a variable with a specified theoretical distribution which was the normal distribution at the current data (testing for distributional assumption for numerical data). Nearly all data were found to be following normal distribution so the following statistical analysis was done:

1- Independent sample t-test: which was used to compare between the means of two normally distributed independent groups. Some data variables were found to have a skewed distribution, so the following non-parametric analysis was done: 


\section{B. Analysis of categorical data:}

Pearson's chi-square test: it is a non-parametric statistic that is used to test for the association (or relationship) between the categories of two independent samples (row and column variables) to reflect a real association between these two variables in the population.

Mont Carlo exact and Fisher's exact test: they are alternatives for the Pearson's chi square test if there were many small expected values.

\section{Level of significance:}

For all statistical tests done, the threshold of significance was fixed at the $5 \%$ level (pvalue). A p-value $>0.05$ indicates non-significant result and the p-value $<0.05$ indicates a significant result and the p-value is the degree of significance. The smaller the p-value obtained, the more significant is the result, the p-value being the probability of error of the conclusion.

\section{RESULTS:}

Table (1): illustrates the socio-demographic characteristics for control and study group . They had a close mean age $26.0 \pm 3.26$ and $25.6 \pm 3.8$ years for the study and control groups respectively. Meanwhile, the majority of women in both groups had secondary and high level of education. Approximately more than two thirds (70\%) of the control group were housewives compared to $58.2 \%$ in the study group. Concerning residence, it was found that, the majority of mothers in both groups were residing in urban areas. Furthermore, this table reveals that, there were no statistically significant difference between both groups regarding the mean of height, weight, and body mass index.

Concerning women obstetric history table (2): shows that they mostly had 1-2 parity in both group, with a mean of $1.4 \pm 0.71$ in the study group and $1.4 \pm 0.8$ in the control group. Meanwhile, the mode of previous delivery was partially similar in both groups and the majority of the studied women had no previous abortion. The characteristics of the current cesarean delivery, it was observed that there was no statistical significant difference between the study and the control group regarding numbers of cesarean delivery and estimated gestational age.

Table (3): presents the baseline characteristics of hemodynamic variables, including the Temperature $\mathrm{HR}, \mathrm{O} 2$ saturation and $\mathrm{Co} 2$ saturation. It was observed that, there was a no statistically significant difference between the both groups regarding body temperature values, 
whereas $\mathrm{p}$ value $>.05$. While there was a statistically significant difference between the both groups $\mathrm{p} \leq 0.05$ regarding HR. O2 saturation and $\mathrm{Co} 2$ saturation.

Table(4): presents the baseline characteristics of hemodynamic variables, including the systolic arterial pressure, the diastolic arterial pressure, and the mean arterial pressure before administration if spinal anathesia. It was observed that, there was a statistically significant difference between the both groups regarding different hemodynamic values, whereas $\mathrm{p}$ value $<, 05$.

Table (5): reveals the distribution of hypotension among hemodynamic variables after 5 minuts of spinal anathesia, it was pointed out that, hypotension of the systolic arterial pressure, the diastolic arterial pressure, and the mean arterial pressure was affected a greater percentage among mothers at the control group than those in the leg compression group with a highly statistically significant difference between both groups. $\left(\mathrm{P}=<0.001^{*}\right)$

Figure (1): shows the distribution of signs of hypotension among the studied mothers in the study and the control group. It was noticed that, both nausea and vomiting as a signs of hypotension were greatly found among mothers at the control group, they were represented as $83.6 \%$ \& $80 \%$ respectively compared to $60.9 \%$ \& $39.1 \%$ among mothers in the leg compression group whereas $\mathrm{p}$ value $<001 * *$

Table (6): displays that, the neonatal characteristics among the leg compression and the control group. It was observed that, there was no statistically significant difference regarding neonatal birth weight and neonatal sex among both groups. On the other hand, there was a highly statistically significant difference between two groups in relation to the Apgar score of the neonate at the first minute and the neonatal acidosis $(\mathrm{p}<.001 * *)$. In addition, there was a statistically significant difference regarding the Apgar score of the neonate at the fifth minute, and admission of the neonate to intensive neonatal care unit.

Table (7): reveals that, the neonatal characteristics among the leg compression and the control group. There was a highly statistically significant difference between two groups in relation to the Apgar score of the neonate at the first minute $(\mathrm{p}<.001 * *)$.

Table (8): shows that, the neonatal characteristics among the leg compression and the control group. There was a highly statistically significant difference between two groups regarding the Apgar score of the neonate at the fifth minute $(p \leq 0.05)$. 
Table (1): Socio- demographic characteristics of women in the study and Control groups $(\mathrm{N}=220)$

\begin{tabular}{|c|c|c|c|c|c|c|}
\hline \multirow[t]{2}{*}{ Personal characteristics } & \multicolumn{2}{|c|}{$\begin{array}{c}\text { Leg } \\
\text { Compression } \\
\text { Group }(n=110)\end{array}$} & \multicolumn{2}{|c|}{$\begin{array}{c}\text { Control Group } \\
(\mathbf{n}=110)\end{array}$} & \multirow[t]{2}{*}{ Test of sig. } & \multirow[t]{2}{*}{$\mathbf{p}$} \\
\hline & No. & $\%$ & No. & $\%$ & & \\
\hline Age of mother & & & & & \multirow{5}{*}{5.293} & \multirow{5}{*}{0.071} \\
\hline $20-25$ & 58 & 52.7 & 62 & 56.4 & & \\
\hline $25-30$ & 49 & 44.5 & 38 & 34.5 & & \\
\hline $30-35$ & 3 & 2.7 & 10 & 9.1 & & \\
\hline mean \& SD & \multicolumn{2}{|c|}{$26.0 \pm 3.26$} & \multicolumn{2}{|c|}{$25.6 \pm 3.8$} & & \\
\hline Educational level & & & & & \multirow{7}{*}{10.044} & \multirow{7}{*}{0.053} \\
\hline Illiterate & 20 & 18.2 & 11 & 10.0 & & \\
\hline Read and write & 7 & 6.4 & 5 & 4.5 & & \\
\hline Basic Education & 0 & 0.0 & 6 & 5.5 & & \\
\hline Secondary Education & 37 & 33.6 & 39 & 35.5 & & \\
\hline University Education & 46 & 41.8 & 48 & 43.6 & & \\
\hline Post graduated & 0 & 0.0 & 1 & 0.9 & & \\
\hline Marital status & & & & & \multirow{3}{*}{2.018} & \multirow{3}{*}{0.498} \\
\hline Married & 110 & 100.0 & 108 & 98.2 & & \\
\hline Divorced & 0 & 0.0 & 2 & 1.8 & & \\
\hline Occupation & & & & & \multirow{3}{*}{3.338} & \multirow{3}{*}{0.068} \\
\hline Working & 33 & 30.0 & 46 & 41.8 & & \\
\hline House wife & 77 & 70.0 & 64 & 58.2 & & \\
\hline Residence & & & & & \multirow{3}{*}{0.793} & \multirow{3}{*}{0.373} \\
\hline Rural & 81 & 73.6 & 75 & 68.2 & & \\
\hline Urban & 29 & 26.4 & 35 & 31.8 & & \\
\hline Weight & \multirow{3}{*}{\multicolumn{2}{|c|}{$\begin{array}{c}65.0-86.0 \\
76.58 \pm 4.96\end{array}$}} & \multirow{3}{*}{\multicolumn{2}{|c|}{$\begin{array}{c}63.0-87.0 \\
77.62 \pm 5.35\end{array}$}} & \multirow{3}{*}{$\mathrm{t}=1.490$} & \multirow{3}{*}{0.138} \\
\hline Min. - Max. & & & & & & \\
\hline Mean \pm SD & & & & & & \\
\hline Height & \multirow{3}{*}{\multicolumn{2}{|c|}{$\begin{array}{l}156.0-186.0 \\
165.72 \pm 5.13\end{array}$}} & \multirow{3}{*}{\multicolumn{2}{|c|}{$\begin{array}{l}112.0-177.0 \\
165.45 \pm 7.43\end{array}$}} & \multirow{3}{*}{$\mathrm{t}=0.306$} & \multirow{3}{*}{0.760} \\
\hline Min. - Max. & & & & & & \\
\hline Mean \pm SD & & & & & & \\
\hline BMI & \multirow{3}{*}{\multicolumn{2}{|c|}{$\begin{array}{c}22.84-30.11 \\
27.88 \pm 1.29\end{array}$}} & \multirow{3}{*}{\multicolumn{2}{|c|}{$\begin{array}{c}20.57-66.17 \\
28.51 \pm 3.91\end{array}$}} & \multirow{3}{*}{$t=1.605$} & \multirow{3}{*}{0.110} \\
\hline Min. - Max. & & & & & & \\
\hline Mean \pm SD & & & & & & \\
\hline
\end{tabular}

*: Statistically significant at $\mathrm{p} \leq 0.05$ 
Table (2): Obstetric history of women in the study and control groups $(\mathrm{N}=220)$

\begin{tabular}{|c|c|c|c|c|c|c|}
\hline \multirow[t]{2}{*}{ Obstetric history } & \multicolumn{2}{|c|}{$\begin{array}{c}\text { Leg Compression } \\
\text { Group }(\mathrm{n}=110)\end{array}$} & \multicolumn{2}{|c|}{\begin{tabular}{|c|}
$\begin{array}{c}\text { Control Group } \\
(\mathrm{n}=110)\end{array}$ \\
\end{tabular}} & \multirow{2}{*}{$\begin{array}{l}\text { Test of } \\
\text { sig. }\end{array}$} & \multirow[t]{2}{*}{$\mathbf{P}$} \\
\hline & No. & $\%$ & No. & $\%$ & & \\
\hline Gravidity & & & & & & \\
\hline 1 Primigravida & 41 & 37.2 & 37 & 33.6 & & \\
\hline $2-$ & 65 & 59.2 & 69 & 62.8 & 4.652 & 0.471 \\
\hline $5+$ & 4 & 3.6 & 4 & 3.6 & & \\
\hline Mean \pm SD & \multicolumn{2}{|c|}{$2.12 \pm 1.11$} & \multicolumn{2}{|c|}{$2.20 \pm 1.18$} & $t=0.529$ & 0.597 \\
\hline Parity & & & & & & \\
\hline 1 & 73 & 66.4 & 78 & 70.9 & & \\
\hline $2-$ & 35 & 31.8 & 30 & 27.3 & 4.695 & \\
\hline $4-$ & 2 & 1.8 & 2 & 1.8 & & 0.137 \\
\hline Mean \pm SD & \multicolumn{2}{|c|}{$1.45 \pm 0.71$} & \multicolumn{2}{|c|}{$1.44 \pm 0.81$} & $\mathrm{t}=0.089$ & 0.929 \\
\hline Mode of previous delivery & & & & & & \\
\hline Normal vaginal delivery( NVD) & 8 & 11.6 & 10 & 13.7 & & \\
\hline C.S & 56 & 81.2 & 60 & 82.2 & 0.774 & $=0.714$ \\
\hline Both NVD and C.S & 5 & 7.2 & 3 & 4.1 & & \\
\hline Number of previous C.S & \multicolumn{2}{|c|}{$(\mathbf{n}=61)$} & \multicolumn{2}{|c|}{$(\mathbf{n}=63)$} & \multirow{5}{*}{3.688} & \multirow{5}{*}{0.158} \\
\hline 1 & 29 & 47.5 & 32 & 50.8 & & \\
\hline 2 & 28 & 45.9 & 21 & 33.3 & & \\
\hline 3 & 2 & 3.3 & 10 & 15.9 & & \\
\hline 4 & 2 & 3.3 & 0 & 0.0 & & \\
\hline $\begin{array}{l}\text { Min. - Max. } \\
\text { Mean } \pm \text { SD. }\end{array}$ & \multicolumn{2}{|c|}{$\begin{array}{c}1.0-4.0 \\
1.62 \pm 0.71 \\
\end{array}$} & \multicolumn{2}{|c|}{$\begin{array}{c}1.0-3.0 \\
1.65 \pm 0.74 \\
\end{array}$} & $\mathrm{t}=0.213$ & 0.832 \\
\hline \multicolumn{7}{|l|}{ Cause of C.S } \\
\hline Cephalopelvic disproportion & 28 & 25.5 & 27 & 24.6 & & \multirow{4}{*}{0.893} \\
\hline Breech & 15 & 13.6 & 13 & 11.8 & & \\
\hline Previous C.S & 62 & 56.4 & 67 & 60.9 & & \\
\hline Large baby & 5 & 4.5 & 3 & 2.7 & & \\
\hline \multicolumn{7}{|l|}{ Estimated gestational age } \\
\hline Min. - Max. & \multicolumn{2}{|c|}{$37.0-40.0$} & \multicolumn{2}{|c|}{$37.0-40.0$} & \multirow{2}{*}{$\mathrm{t}=1.312$} & \multirow{2}{*}{0.191} \\
\hline Mean \pm SD & \multicolumn{2}{|c|}{$38.48 \pm 1.0$} & \multicolumn{2}{|c|}{$38.67 \pm 1.11$} & & \\
\hline
\end{tabular}

$\chi^{2}, \mathrm{p}: \chi^{2}$ and $\mathrm{p}$ values for Chi square test for comparing between the two groups

${ }^{\mathrm{MC}} \mathrm{P}: \mathrm{p}$ value for Monte Carlo for Chi square test for comparing between the two groups

$\mathrm{T}, \mathrm{p}: \mathrm{t}$ and $\mathrm{p}$ values for Student $\mathrm{t}$-test for comparing between the two groups

Note: $(\mathrm{NVD}=$ Normal Vaginal Delivery; C.S = Cesarean Section $)$ 
Table (3): Hemodynamic contains of women in the study and control groups $(\mathrm{N}=220)$

\begin{tabular}{|l|c|c|c|c|}
\hline & $\begin{array}{c}\text { Leg } \\
\text { Compression } \\
\text { Group (n=110) }\end{array}$ & $\begin{array}{c}\text { Control Group } \\
(\mathbf{n}=\mathbf{1 1 0})\end{array}$ & $\begin{array}{c}\text { Test of } \\
\text { sig }\end{array}$ & P \\
\hline Temperature & $36.20-38.80$ & $36.20-38.80$ & $\mathrm{t}=0.175$ & 0.861 \\
Min. - Max. & $37.0 \pm 0.41$ & $37.01 \pm 0.42$ & & \\
Mean \pm SD. & $70.0-88.0$ & $70.0-89.0$ & $\mathrm{t}=2.931^{*}$ & $0.004^{*}$ \\
\hline HR & $77.54 \pm 3.30$ & $79.08 \pm 4.44$ & & \\
Min. - Max. & & & & \\
Mean \pm SD. & $79.0-99.0$ & $78.0-100.0$ & $\mathrm{t}=4.453^{*}$ & $<0.001^{*}$ \\
\hline O2 saturation & $96.58 \pm 2.78$ & $93.22 \pm 7.42$ & & \\
\hline Min. - Max. & $30.0-38.0$ & $33.0-37.0$ & $\mathrm{t}=5.092^{*}$ & $<0.001^{*}$ \\
Mean \pm SD. & $33.21 \pm 0.81$ & $33.95 \pm 1.30$ & & \\
\hline Co2 saturation & & & & \\
Min. - Max. & & & & \\
Mean \pm SD. & & & & \\
\hline
\end{tabular}

$\mathrm{T}, \mathrm{p}: \mathrm{t}$ and $\mathrm{p}$ values for Student $\mathrm{t}$-test for comparing between the two groups

*: Statistically significant at $\mathrm{p} \leq 0.05$

Note. $(\mathrm{HR}=$ Heart Rate $)$ Measures Uses automatic machines 
Table (4): Distribution of the two studied groups according to baseline of homodynamic variables of mothers under study

\begin{tabular}{|l|c|c|c|c|}
\hline & $\begin{array}{c}\text { Leg Compression } \\
\text { Group }(\mathbf{n = 1 1 0})\end{array}$ & $\begin{array}{c}\text { Control Group } \\
(\mathbf{n}=\mathbf{1 1 0})\end{array}$ & $\begin{array}{c}\text { Test of } \\
\text { sig }\end{array}$ & \multicolumn{1}{|c|}{$\mathbf{p}$} \\
\hline S.A.P base line (mmHg) & $110.0-131.0$ & $95.0-137.0$ & $\mathrm{t}=2.990^{*}$ & $0.003^{*}$ \\
Min. - Max. & $120.25 \pm 6.69$ & $117.11 \pm 8.74$ & & \\
\hline D.A.P. base line \pm SD. & & & & \\
(mmHg) & $70.0-90.0$ & $60.0-90.0$ & $\mathrm{t}=3.843^{*}$ & $<0.001^{*}$ \\
Min. - Max. & $81.45 \pm 6.25$ & $77.45 \pm 8.98$ & & \\
Mean \pm SD. & $83.0-102.0$ & $70.0-102.0$ & $\mathrm{t}=4.177^{*}$ & $<0.001^{*}$ \\
\hline M A.P base line (mmHg) & $94.22 \pm 5.83$ & $89.81 \pm 9.41$ & & \\
\hline Min. - Max. & & & & \\
Mean \pm SD. & & & & \\
\hline
\end{tabular}

$\mathrm{T}, \mathrm{p}: \mathrm{t}$ and $\mathrm{p}$ values for Student $\mathrm{t}$-test for comparing between the two groups

*: Statistically significant at $\mathrm{p} \leq 0.05$

Note. $(\mathrm{SAD}=$ systolic arterial pressure DAP $=$ diastolic arterial pressure; $\mathrm{MAP}=$ mean arterial pressure.$)$ 
Table (5): Distribution of hypotension of different hemodynamic studied variables among mothers under study

\begin{tabular}{|l|c|c|c|c|}
\hline Hypotension of S.A.P & $\begin{array}{c}\text { Leg Compression } \\
\text { Group }(\mathbf{n = 1 1 0})\end{array}$ & $\begin{array}{c}\text { Control Group } \\
(\mathbf{n = 1 1 0})\end{array}$ & $\begin{array}{c}\text { Test of } \\
\text { sig }\end{array}$ & P \\
Min. - Max. & $90.0-100.0$ & $80.0-95.0$ & $\mathrm{t}=12.674^{*}$ & $<0.001^{*}$ \\
Mean \pm SD. & $94.85 \pm 4.76$ & $83.19 \pm 3.75$ & & \\
\hline Hypotension of D.A.P & $60.0-60.0$ & $40.0-60.0$ & $\mathrm{t}=25.243^{*}$ & $<0.001^{*}$ \\
Min. - Max. & $60.0 \pm 0.0$ & $48.35 \pm 4.33$ & & \\
Mean \pm SD. & $70.0-90.0$ & $47.0-71.60$ & & \\
\hline Hypotension of M.A.P & $71.96 \pm 5.08$ & $59.12 \pm 3.63$ & $\mathrm{t}=15.587^{*}$ & $<0.001^{*}$ \\
Min. - Max. & & & \\
\hline Mean \pm SD. & & & & \\
\hline
\end{tabular}

$\mathrm{T}, \mathrm{p}: \mathrm{t}$ and $\mathrm{p}$ values for Student $\mathrm{t}$-test for comparing between the two groups

*: Statistically significant at $\mathrm{p} \leq 0.05$

Note.$(\mathrm{SAD}=$ systolic arterial pressure $; \mathrm{DAP}=$ diastolic arterial pressure; $\mathrm{MAP}=$ mean arterial pressure.$)$ 


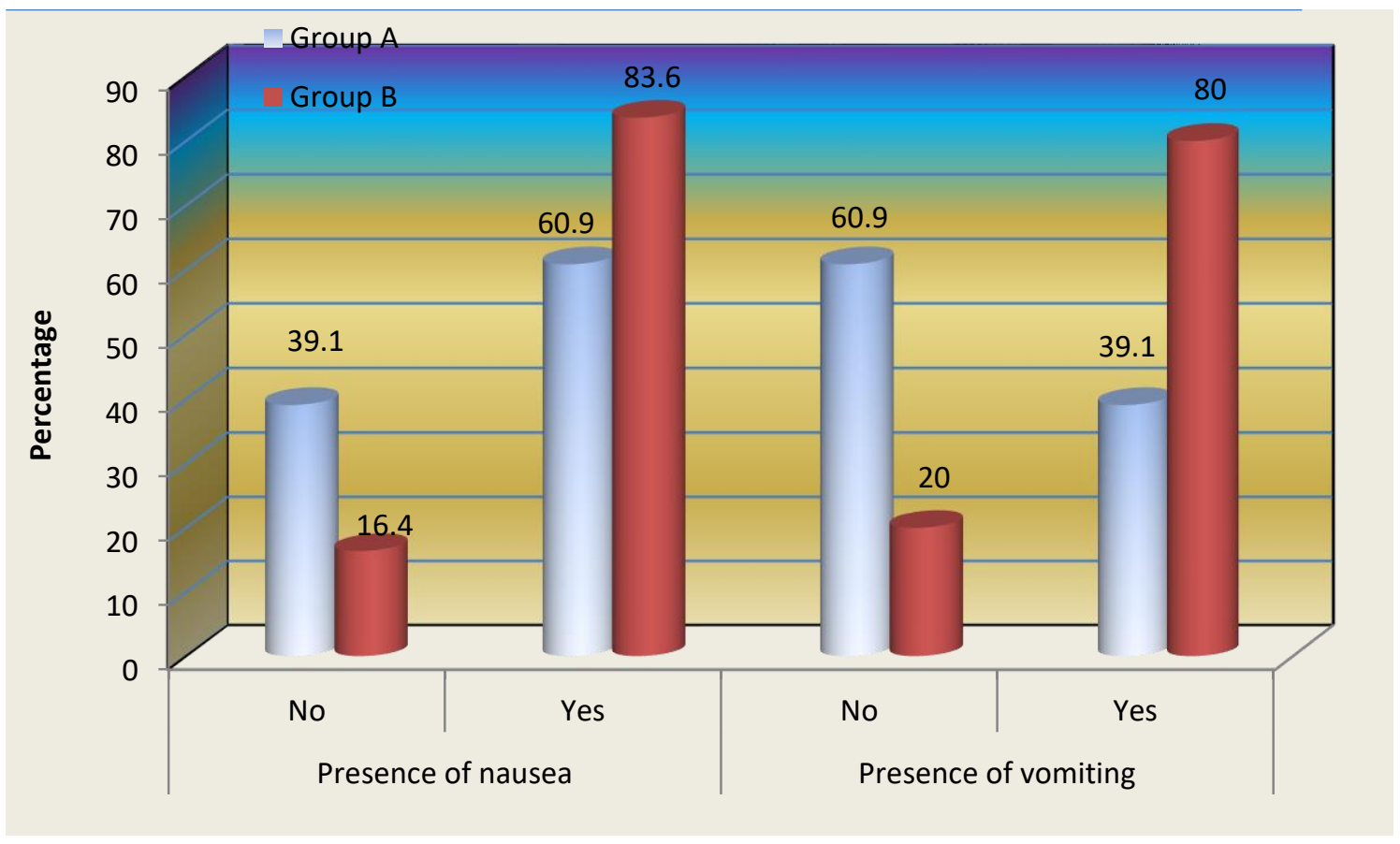

Group $\mathrm{A}=$ le compression group $\mathrm{B}=\mathrm{control}$ group

Figure (1): Presence of nausea and vomiting 
Table (6): Distribution of the two studied groups according to neonatal outcomes $(\mathrm{N}=220)$

\begin{tabular}{|c|c|c|c|c|c|c|}
\hline \multirow[t]{2}{*}{ neonatal outcomes } & \multicolumn{2}{|c|}{\begin{tabular}{|c|} 
Leg Compression \\
Group $(n=110)$
\end{tabular}} & \multicolumn{2}{|c|}{$\begin{array}{c}\text { Control Group } \\
(\mathbf{n}=110)\end{array}$} & & \multirow{2}{*}{$\mathbf{p}$} \\
\hline & No. & $\%$ & No. & $\%$ & & \\
\hline \multicolumn{7}{|l|}{ Neonatal birth weight } \\
\hline$<2500$ & 10 & 9.1 & 10 & 9.1 & \multirow{3}{*}{5.838} & \multirow{3}{*}{0.054} \\
\hline $2500-4000$ & 90 & 81.8 & 97 & 88.2 & & \\
\hline$>4000$ & 10 & 9.1 & 3 & 2.7 & & \\
\hline \multicolumn{7}{|l|}{ Neonatal sex } \\
\hline Male & 65 & 59.1 & 58 & 52.7 & \multirow{2}{*}{0.904} & \multirow{2}{*}{0.342} \\
\hline Female & 45 & 40.9 & 52 & 47.3 & & \\
\hline \multicolumn{7}{|l|}{ Apgar score at $1^{\text {st }}$ min } \\
\hline Normal (7-10) & 82 & 74.5 & 64 & 58.2 & \multirow{3}{*}{$6.567^{*}$} & \multirow{3}{*}{$0.039^{*}$} \\
\hline Moderate Risk (4-6) & 17 & 15.5 & 27 & 24.5 & & \\
\hline High Risk (0-3) & 11 & 10.0 & 19 & 17.3 & & \\
\hline \multicolumn{7}{|l|}{ Apgar score at $5 \mathrm{~min}$} \\
\hline Normal (7-10) & 88 & 80.0 & 70 & 63.6 & \multirow{3}{*}{$7.309^{*}$} & \multirow{3}{*}{$0.026^{*}$} \\
\hline Moderate Risk (4-6) & 11 & 10.0 & 21 & 19.1 & & \\
\hline High Risk (0-3) & 11 & 10.0 & 19 & 17.3 & & \\
\hline \multicolumn{7}{|l|}{ Neonatal Acidosis } \\
\hline No & 92 & 83.6 & 70 & 63.6 & \multirow{2}{*}{11.40} & \multirow{2}{*}{$.001 * *$} \\
\hline Yes & 18 & 16.4 & 40 & 36.4 & & \\
\hline \multirow{3}{*}{$\begin{array}{l}\text { Admission to intensive care } \\
\text { No }\end{array}$} & & & & & \multirow{3}{*}{5.80} & \multirow{3}{*}{$0.049^{*}$} \\
\hline & 88 & 80 & 70 & 63.6 & & \\
\hline & 22 & 20 & 40 & 36.7 & & \\
\hline
\end{tabular}

$\chi^{2}, \mathrm{p}: \chi^{2}$ and $\mathrm{p}$ values for Chi square test for comparing between the two groups

*: Statistically significant at $\mathrm{p} \leq 0.05$ 
Table (7): Distribution of the two studied groups according to Apgar score at 1st minute $(\mathrm{N}=220)$

\begin{tabular}{|c|c|c|c|c|c|c|}
\hline & \multicolumn{2}{|c|}{$\begin{array}{l}\text { Leg Compression } \\
\text { Group }(\mathrm{n}=110)\end{array}$} & \multicolumn{2}{|c|}{$\begin{array}{c}\text { Control Group } \\
(\mathbf{n}=\mathbf{1 1 0})\end{array}$} & \multirow{2}{*}{$\begin{array}{c}\text { Test of } \\
\text { sig. }\end{array}$} & \multirow[t]{2}{*}{$\mathbf{P}$} \\
\hline & \begin{tabular}{|l} 
No. \\
\end{tabular} & $\%$ & No. & $\%$ & & \\
\hline \multicolumn{7}{|l|}{ Respiratory after $1 \mathrm{~min}$} \\
\hline Absent & 2 & 1.8 & 6 & 5.5 & \multirow{3}{*}{$45.678^{*}$} & \multirow{3}{*}{$<0.001^{*}$} \\
\hline Slow irregular & 18 & 16.4 & 67 & 60.9 & & \\
\hline Good cry & 80 & 72.8 & 37 & 33.5 & & \\
\hline \multicolumn{7}{|l|}{ Heart rate after $1 \mathrm{~min}$} \\
\hline Absent & 2 & 1.8 & 6 & 5.4 & \multirow{3}{*}{6.378} & \multirow{3}{*}{$\begin{array}{c}{ }^{\mathrm{MC}} \mathrm{p}= \\
0.040^{*}\end{array}$} \\
\hline Below $100 \mathrm{~b} / \mathrm{min}$ & 32 & 29.1 & 46 & 41.1 & & \\
\hline Over $100 \mathrm{~b} / \mathrm{min}$ & 76 & 69.1 & 60 & 53.6 & & \\
\hline \multicolumn{7}{|l|}{ Muscle tone after $1 \mathrm{~min}$} \\
\hline Flaccid & 5 & 4.5 & 6 & 5.5 & \multirow{3}{*}{$33.513^{*}$} & \multirow{3}{*}{$<0.001^{*}$} \\
\hline Some flexion of limbs & 25 & 22.7 & 66 & 60.0 & & \\
\hline Well Flexed & 80 & 72.7 & 38 & 34.5 & & \\
\hline \multicolumn{7}{|l|}{ Reflex after 1min } \\
\hline No Response & 9 & 8.2 & 17 & 15.5 & \multirow{3}{*}{$51.990^{*}$} & \multirow{3}{*}{$<0.001^{*}$} \\
\hline Grimace & 21 & 19.1 & 66 & 60.0 & & \\
\hline Cough or sneeze & 80 & 72.7 & 27 & 24.5 & & \\
\hline \multicolumn{7}{|l|}{ Color after 1min } \\
\hline Blue or pale & 18 & 16.4 & 30 & 27.3 & & \multirow{3}{*}{$0.014^{*}$} \\
\hline Body pink limbs blue & 30 & 35.5 & 44 & 40.0 & & \\
\hline All pink & 53 & 48.2 & 36 & 32.7 & & \\
\hline
\end{tabular}

$\chi^{2}, \mathrm{p}: \chi^{2}$ and $\mathrm{p}$ values for Chi square test for comparing between the two groups

${ }^{M C} \mathrm{P}$ : $\mathrm{p}$ value for Monte Carlo for Chi square test for comparing between the two groups

$\mathrm{T}, \mathrm{p}: \mathrm{t}$ and $\mathrm{p}$ values for Student $\mathrm{t}$-test for comparing between the two groups

*: Statistically significant at $\mathrm{p} \leq 0$ 
Table (8): Distribution of the two studied groups according to Apgar score at $5^{\text {th }}$ minute $(\mathrm{N}=220)$

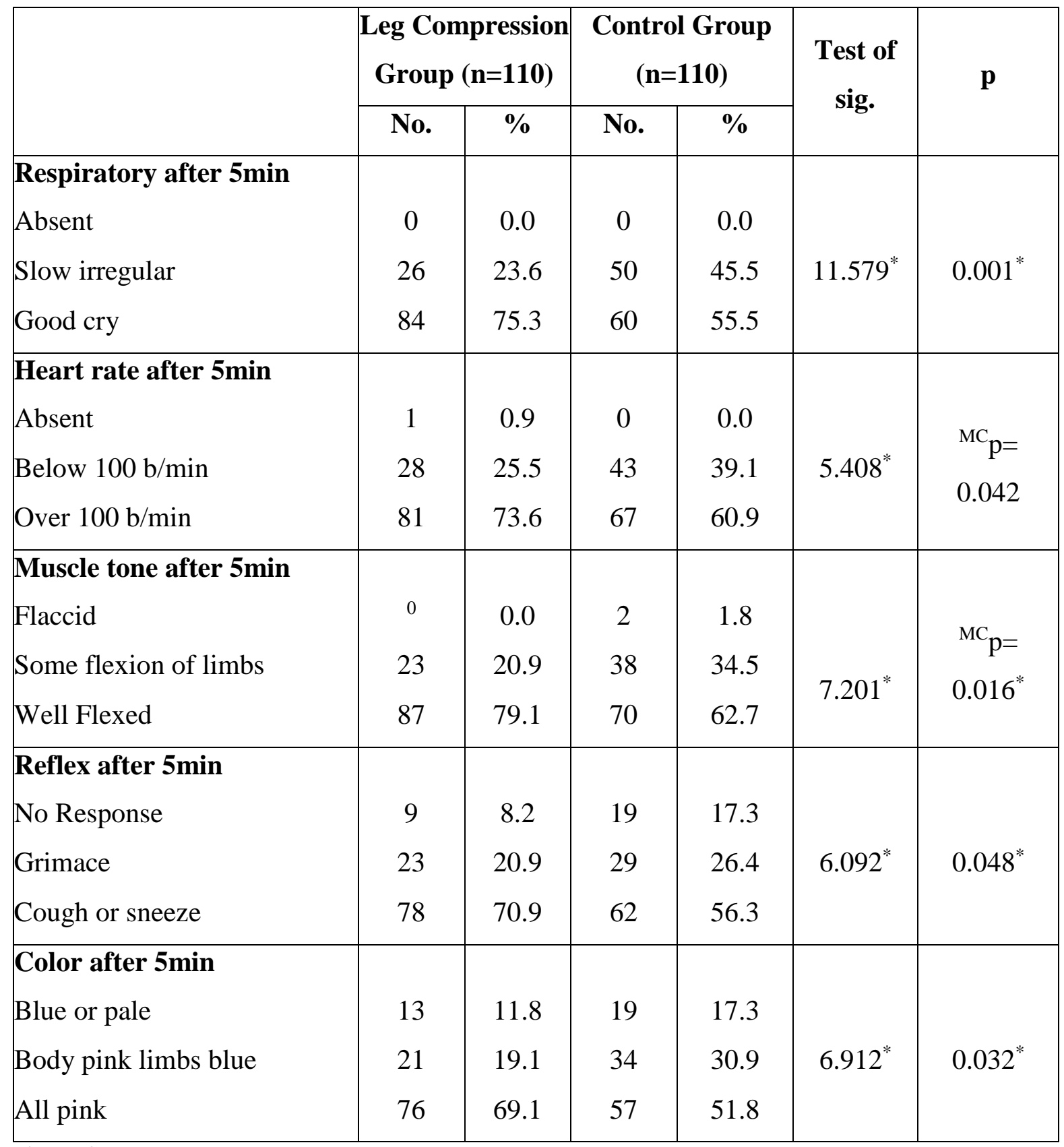

$\chi^{2}, p: \chi^{2}$ and $p$ values for Chi square test for comparing between the two groups

${ }^{M C} \mathrm{P}: \mathrm{p}$ value for Monte Carlo for Chi square test for comparing between the two groups

*: Statistically significant at $\mathrm{p} \leq 0.05$ 


\section{DISCUSSION:}

Spinal anaesthesia is the most common anesthetic technique for caesarean delivery. It help to avoid risks of general anaesthesia and facilitating effective postoperative pain relief. Spinal hypotension is the commonest clinical problem of spinal anaesthesia that is usually accompanied by nausea and vomiting. Severe spinal hypotension can result in serious risks to mother (including loss of consciousnes) and neonate (including lack of oxygen and brain damage)( Klohr et al 2010).

Spinal anesthesia is undoubtedly the most popular technique of anesthesia for cesarean section. However, spinal anesthesia is associated with a high incidence of maternal hypotension which can result in fetal distress and maternal discomfort (Betrán et al 2016 ).so, the aim of the present study was to evaluate effect of lower leg compression technique for reducing spinal induced hypotension during cesarean delivery.

The current study identify the danger signals denoting complication among the studied sample. It was expected to find out that women in the study group were less likely to experience postoperative complications compared to the control group. This could be explained by the fact that evidence based nursing practices, providing enough time and therapeutic communication, have demonstrated that greater improvements in patient's outcomes was observed among women in the study group than the control group.

As regarding effect of leg compression on reducing spinal induced hypotension during cesarean delivery the present study pointed out that there was a highly statistical significant difference between leg compression and control groups regarding hypotension of systolic arterial pressure, diastolic arterial pressure, and mean arterial pressure, as the high percentages of hypotension were observed among women at control group. These finding may be due to that during spinal anaethesia for cesarean delivery the major hemodynamic problem is inadequate venous return, and compressing the legs following spinal anaethesia increases venous return at the time that this is required and at a rate faster than can be achieved by intravenous infusion these findings are in the same line with (Adsumell etal,2003) in the study to evaluate the effect of sequential compression device (SCD) with thigh-high sleeves supports mean arterial pressure during caesarean section under spinal anaesthesia, their findings pointed 
out that a greater than $20 \%$ decrease in MAP occurred in $52 \%$ of patients in the SCD group versus $92 \%$ in the control group ( $\mathrm{P}=0.004$, odds ratio $0.094,95 \%$ CI $0.018 \pm 0.488$ ).

In addition in Egypt Khedr (2013),carried out a study to evaluate preventive measures to reduce post - spinal anesthesia hypotension for elective cesarean delivery, it was found that a significant difference was noticed among the groups, whereas GI (wrapping \& elevation) had a higher MSAP, lower percent of hypotension women late onset time of hypotension .

Moreover(Emmett, Cyna, Andrew,\& Simmons,2006) conducted a study to assess the effects of prophylactic interventions for hypotension following spinal anaesthesia for caesarean section. The study presented that interventions such as colloids, ephedrine, phenylephrine or lower leg compression can reduce the incidence of hypotension, none have been shown to eliminate the need to treat maternal hypotension during spinal anaesthesia for caesarean section.

The incidence of post operative nausea and vomiting after spinal anaethesia has remained high and has a major negative impact on patient satisfaction about the overall surgical experience.The preset study added that nausea and vomiting were observed to affect a higher percent of control group than these in leg compression group.these findings may be related to that hypotension incidence was high among control group , which may lead to brain stem ischemia, which is thought to activate the circulatory, respiratory, and vomiting centers grouped together in the medulla.

As regarding neonatal outcomes, the present study revealed that there was no statistical significant difference between leg compression and control group regarding studied neonates weight,sex .these findings were agreed with Adsumell etal,(2003) who added that there was no significant difference between studied group regarding neonatal birth weight and sex.

In relation the neonatal condition, as assessed by Apgar scores and umbilical cord blood gases, the present study pointed out that they were excellent among leg compression group, and there was a significant difference between both groups. These findings may be related to that utero-placental circulation and hence fetal wellbeing depends on maternal blood pressure. Spinal anaesthesia for Caesarean section can cause sudden and severe drops in blood pressure thus threatening fetal and neonatal acid-base balance. Neonates born to mothers with hypotension are significantly more acidotic than these who don't. 
These findings are agreed with Ueyama (2009), in the study to examine the effects of crystalloid and colloid preload on blood volume on the parturient undergoing spinal anaesthesia for cesarean section. Who believed that maternal hypotension had a strong correlation with neonatal academia. In addition Reynolds and Seed(2005), who added that there is a positive correlation between Anesthesia for Caesarean section and neonatal acid-base status .

\section{CONCLUSION:}

\section{Based on the findings of the present study findings, it could be concluded that:}

According to the results of the present study, lower leg compression for women under elective cesarean section with spinal anaethesia is more effective measure to improve spinal induced hypotension during cesarean delivery and neonatal acidosis.

\section{RECOMMENDATIONS:}

\section{On the basis of the most important findings of the study, the following:-}

1. The leg compression can be used as an integral part of pei operative care and may be supplemented with booklets and pamphlets.

2. Implementation of a training program for women to utilize leg compression socks for women underwent Cs.

3. Mother classes could be conducted in antenatal settings, outpatient clinics, to discuss the care that should be provided to women undergoing CS and possible complications.

4. Further researches are needed in different settings to develop standereized nursing protocole of leg compression..

\section{REFERENCES:}

Adsumelli RS, Steinberg ES, Schabel JE, Saunders TA, Poppers PJ.(2003): Sequential compression device with thigh- high sleeves supports mean arterial pressure during Caesarean section under spinal anaesthesia. Br J Anaesth. Nov;91(5):695-8. 
Allen TK, George RB, White WD, Muir H a., Habib AS.(2010): A double-blind, placebo-controlled trial of four fixed rate infusion regimens of phenylephrine for hemodynamic support during spinal anesthesia for cesarean delivery. Anesth Analg.; 111(5): 1221-9.

Apgar V. (1953): A proposal for a new method of evaluation of the newborn infant. Curr Res AnesthAnalg.; 32(4): 260-7.

Association of Women's Health, Obstetric and Neonatal Nurses (2006): The Compendium of Postpartum Care. Washington. Available at http://proquest.umi.com.zdl.zu.edu.eg. Accessed at March, 30, 2011.

Association of Women's Health, Obstetric and Neonatal Nurses (2001): Guidelines for perioperative and per anesthesia/anesthesia care of the pregnant woman, AWHONN, Washington, DC.

Awadalla A (2016): Monitoring of Upward Trend of C-Sections Performed Per Year at An Egyptian University Maternity Hospital: An Economic Barrier in Low-Income Countries International Journal of Obstetrics and Gynecology. Research (IJOGR) 3 (3): 257-270.

Betran A P, Merialdi M, Lauer J A, Bing Shun W, Thomas J, \& Van Look (2007): Rates of Cesarean Section Analysis of Global, Regional and National Estimates Paediatr. Perinat Epidemiol, 21 (2):98-113.

Betrán AP, Ye J, Moller A-B, Zhang J, Gülmezoglu AM, Torloni MR (2016): The Increasing Trend in Caesarean Section Rates: Global, Regional and National Estimates: 19902014. PLoS ONE; 11(2): e0148343. doi:10.1371/journal.pone.0148343.

Bonney EA and Myers JE (2011): Caesarean section techniques and complications. Obstetrics, Gynaecology \&Reproductive Medicine; 21(4): 97-102.

Briggs GG, Freeman RK, and Yaffe SJ (2005): Drugs in Pregnancy and Lactation. $2^{\text {nd }}$ ed., Williams \& Wilkins. Philadelphia: Lippincott: 297-365.

BonneyEA, and MyersJE. (2011): Caesarean section techniques and complications. Obstetrics, Gynaecology\&Reproductive Medicine; 21(4): 97-102. 
Butwick a. J, Columb MO, Carvalho B.(2015): Preventing spinal hypotension during Caesarean delivery: What is the latest? Br J Anaesth. 114(2): 183-6.

Cluver G, Novikova N, Hofmeyr J, Hall D(2013):Maternal position during caesarean section for preventing maternal and neonatal complications. Cochrane Database Syst Rev. 2013 Mar 28 ( 3):CD007623. doi: 10.1002/14651858.CD007623.pub3.

Cunningham FG, Leveno KJ, Bloom SL et al., (2010): Cesarean Delivery and Peripartum Hysterectomy, Williams Obstetrics, Chapter25, 23 ${ }^{\text {rd }}$ edition, by the McGraw-Hill companies: 544- 560.

Cunningham FG, Larry CG, \&Norman FG. (2010): Cesarean delivery and postpartum hysterectomy. Williams Obstetrics, 23rd ed. Appleton and Lange., California: 544-564.

Dawood A S, Dawood AG S, El-Shwaikh S L (2017):A Three Year Retrospective Study of Caesarean Section Rate at Tanta University Hospitals Journal of Gynecology and Obstetrics; 5(2): 25-30

Emmett RS, Cyna AM, Andrew M, Simmons SW. (2006):Update of Cochrane Database Syst Rev. (4):CD002251.

FarrukMA, AneelaP\&VigarA.(2008):Prevention of hypotension in cesarean delivery under spinal anesthesia; the combination of modified supine wedged position, crystalloid cohydration and prophylactic atropine. Pakistan .Armed.Forces Medical Journal, Issue No.4, Issue Month December.

Grainger S. Lanneau, Jr, MD Patrick Muffley, MD (2011): Cesarean birth, surgical technique, Clinical Instructor, (Vol 2, Chaps 74, 75).

Gregory K. D., Korst L. M., \& Gornbein J. A., et al (2002): Using Administrative Data to Identify Indications for Elective Primary Cesarean Delivery. Health Serve Res; 37:1387 1401.

Habib AS, Ituk,UT, \& CooterM . (2016): Retrospective comparison of ephedrine and phenylephrine for the treatment of spinal anesthesia induced hypotension in pre-eclampsia patients Curr Med Res Opin, 29: 1-4. 
Habib AS.(2012): A review of the impact of phenylephrine administration on maternal hemodynamics and maternal and neonatal outcomes in women undergoing cesarean delivery under spinal anesthesia. AnesthAnalg .114:377-90.

HasaninA, Aiyad A, Elsakka1 A, KamelA, FouadR, OsmanM, MokhtarA, RefaatS, and Hassabelnaby A. (2017): Leg elevation decreases the incidence of post-spinal hypotension in cesarean section: BMC Anesthesiology 17:60 DOI 10.1186/s12871-017-0349-8

Health Protection Agency (HPA)( 2011):High Impact Intervention (care bundle to prevent surgical site infection). Avaliable:

http://webarchive.nationalarchives.gov.uk/20120118164404/hcai.dh.gov.uk/files/2011/03/2011 _-03-14-HII-Prevent-Surgical-Site-infection-FINAL.pdf [Accessed 23/02/2015]

Jain K, Makkar jk, Subramani V P, GanderP, Kumar PA.(2016): randomized trial comparing prophylactic phenylephrine and ephedrine infusion during spinal anesthesia for emergency cesarean delivery in cases of acute fetal compromise.J Clin Anesth, 34 pp. 208-215.

James, M. \& Martinez, E.A. (2008): Antibiotics and perioperative infections. Best Practice \& Research Clinical Anesthesiology. 22 (3) 571-584.

Khawaja M, Choueir N and Jurdi R (2009): Hospital-based cesarean section rates in the Arab region: an overview.East Mediterr Health J.; 15(2): 458-469. Available at: http://www.ncbi.nlm.nih.gov.

Klöhr S1, Roth R, Hofmann T, Rossaint R, Heesen M.(2010): Definitions of hypotension after spinal anaesthesia for caesarean section: literature search and application to parturients. INTER. J .Acta Anaesthesiol Scand 54: 909-9 2.

Khedr N F. (2011): Preventive Measures to Reduce Post - spinal Anesthesia Hypotension for Elective Cesarean Delivery . Journal of American Science.7(2).

Kluger MT. (2000). Ephedrine may predispose to arrhythmias in obstetric anaesthesia. Anaesth Intensive Care. 2000;28:336. 
Lee H M , Kim SH , Hwang BY, Yoo BW, Koh WU ,\& Jang DM. (2015): The effects of prophylactic bolus phenylephrine on hypotension during low-dose spinal anesthesia for cesarean section.Int J Obstet Anesth, 15 (25): 17-22.

Loubert C., (2012):Fluid and vasopressor management for Cesarean delivery under spinal anesthesia: Continuing professional development. Can J Anaesth. 59:604-19.

Mohamed A., Elazhary A. Abdelhady R.,\& SadekB. ( 2016) : Utilization of lower leg compression technique for reducing spinal induced hypotension, and related risks for mothers and neonates during cesarean delivery. Journal of Nursing Education and Practice. 6 (7):11-18

Mahmoud G.A.,(2007): The prevalence of women undergoing cesarean section in Women's Health center, Assiut University Hospital, thesis of Doctorate in obstetrics and gynecology.

Maloni, J., and Park, S., (2005): Post-Partum Symptoms after Ante Partum Bed Rest. Journal of Obstetric, Gynecological and Neonatal Nursing: 34 (2) : 163-171.

Matsota,P A. Karakosta, A. Pandazi, D. Niokou, K. Christodoulaki, G. Kostopanagioto u(2015):The effect of 0.5 L 6\% hydroxyethyl starch 130/0.42 versus 1 L Ringer's lactate preload on the hemodynamic status of parturients undergoing spinal anesthesia for elective cesarean delivery using arterial pulse contour analysis J Anesth, 29 (3) : 352-359.

Mercier FJ , Diemunsch, A.S. Ducloy,Bouthors, A. Mignon, M.Fischler, J.M. Malinovsky, (2014): 6\% Hydroxyethyl starch (130/0.4) vs Ringer's lactate preloading before spinal anaesthesia for Caesarean delivery: the randomized, double-blind, multicentre CAESAR trial Br Anaesth, 113 (3): 459-467.

Ministry of Health and Populations [Egypt] (2015): El-ZanatyAssociates [Egypt], ICF International. The 2014 Egyptdemographic and Health Survey (2014 EDHS). Main Findings. Cairo, Egypt 2015.

Mercier FJ, Augè M, Hoffmann C, Fischer C, \&Le Gouez A. (2013): Maternal hypotension during spinal anesthesia for caesarean delivery. Minerva Anestesiol. 79 (1):62-73.

Mohta M, Janani SS, Sethi AK, Agarwal D, Tyagi A. (2010) Comparison of phenylephrine hydrochloride and mephentermine sulphate for prevention of post spinal hypotension. Anaesthesia. 2010;65:1200-5 
Ngan Kee WD, Khaw KS, Ng FF.( 2005) Prevention of hypotension during spinal anesthesia for cesarean delivery: An effective technique using combination phenylephrine infusion and crystalloid cohydration. Anesthesiology.;103:744-50

National Institute for Health and Clinical Excellence (2006): Routine postnatal care of women and their babies: pp 4-46. Available at: www.nice.org.uk/.../pdf/CG37NICEguideline. Accessed at 15, November, 2011.

National Institute for Health and Clinical Excellence (NICE). 2011. Caesarean section https://www.nice.org.uk/ guidance/cg132/chapter/ 1-guidance\#/procedural-aspects-of-cs

Odom-Forren J (2006): Preventing surgical site infections. Nursing; 36:58-63. Available at: http://www.wounds-uk.com/pdf/content_9406.pdf. Accessed at November, 5, 2011

Oh AY, Hwang JW, Song IA, Kim MH , Ryu JH, \& ParkHP. (2014):Influence of the timing of administration of crystalloid on maternal hypotension during spinal anesthesia for cesarean delivery: preload versus coload BMC Anesthesiol, 14 (1) : 36.

Orshan, S A. (2007): Postpartum period and newborn care, Maternity, newborn, and women's health nursing : comprehensive care across the lifespan. ,unit4, Philadelphia : Lippincott Williams \& Wilkins:706

Oxford English Dictionary (2013): Definition of cesarean in US English https://en.wikipedia.org/wiki/Oxford_English_Dictionary

Powell M, MathruM, Brandon R, Patel M, FrölichM.(2014):Assessment of endothelial glycocalyx disruption in term parturients receiving a fluid bolus before spinal anesthesia: a prospective observational study Int J Obstet Anesth, 23 (4) :330-334

Powell S. (2001): Coreoumculum for Case Management. Philadelphia, New York, Baltimore: Lippincott: 91-93.

Reynolds F.,\&Seed PT.,(2005) :Anaesthesia for Caesarean section and neonatal acidbase status: a meta-analysis- Anaesthesia, 260, ( 7):633-736. 
Rubin R., (2007): "Battle lines drawn over C-sections". USA Today. http://www.usatoday.com/news/health/2005-08-23-csection-battle_x.htm. Retrieved 2008-02$\underline{09}$.

Sng B.L., Tan H.S., Sia A.T.(2014): Closed-loop double-vasopressor automated system vs manual bolus vasopressor to treat hypotension during spinal anesthesia for caesarean section: a randomized controlled trial Anesthesia, 69 (1) (2014): 37-45

Simpson KR and Creehan PA (2008): Labor and birth. Perinatal Nursing. 3rd ed. Philadelphia: Lippincott Williams \& Wilkins: 300-398.

Shipra S and Brown S (2006):Malpresentations in labour. Current Obstetrics \&Gynaecology; 16: 234-241. Available at: http://www.sciencedirect.com.zdl.zu.edu.eg. Accessed at April, 4, 2011.

Souza JP, Gulmezoglu A, Lumbiganon P, Laopaiboon M, Carroli G, Fawole B.(2010): Caesarean section without medical indications is associated with an increased risk of adverse short-term maternal outcomes: the 2004-2008 WHO Global Survey on Maternal and Perinatal Health. BMC medicine ; 8:71. doi: 10.1186/1741-7015-8-71 PMID: 21067593.

Simpson KR, and Creehan PA. (2008): Labor and birth. Perinatal Nursing. $3^{\text {rd }}$ ed. Philadelphia: Lippincott Williams \& Wilkins: 300-398.

Sunil S., Gayathri. (2010): Cesarean Section, Types and Indications of C-Section http://www.medindia.net/surgicalprocedures/caesarean-section-types-and-indications.

Sujata N, Arora D, Panigrahi BP, Hanjoora VM.( 2012) A sequential compression mechanical pump to prevent hypotension during elective cesarean section under spinal anesthesia. Int J Obstet Anesth.;21:140-5.

Tamilselvan P, Fernando R, Bray J, . Sodhi M, Columb.The effects of crystalloid and colloid preload on cardiac output in the parturient undergoing planned cesarean delivery under spinal anesthesia: a randomized trial Anesth. Analg. 109 (6) (2009): 1916-1921.

Tanner, J., Norrie, P., \&Melen, K. 2011. Preoperative hair removal to reduce surgical site infection. Cochrane Database Syst Review. Issue 11. 
U.S. Department of Health and Human Services (2010): Healthy People. Washington, DC: Government Printing Office, 2000.

Ueyama H,He YL, Tanigami H, Mashimo T, Yoshiya (2009): Effects of crystalloid and colloid preload on blood volume in the parturient undergoing spinal anesthesia for elective Cesarean section. Anesthesiology. 91(6):1571-6.

XiaoW Q, Duan L, Zhao X, Chi F, Wang D,\& Ma(2015):Goal-directed fluid therapy may improve hemodynamic stability in parturient women under combined spinal epidural anesthesia for cesarean section and newborn well-being.J Obstet Gynaecol Res, 41 (10) pp. 1547-55.

Yassin K, \&Saida G. (2012): Levels and Determinants of Caesarean Deliveries in Egypt: Pathways to Rationalization. Internet Journal of World Health and Societal Politics. 7: $1-8$.

Zaitoun M (2011): Obstetrics, Cesarean section. $5^{\text {th }}$ edition; Chapter 7, Egypt:

فاعليه استخدام تقتيه ضغط الساق لتقليل انخفاض ضغط الام الناتج عن التخدير الشوكى للنساء اللاتى

$$
\text { يخضعن للولاده القيصريه }
$$

د/محمد نزار محمد الثحات 1, د/ انعام حسن عبد العاطى 2,د/ مها رمضان على 3, آية حمدينو محمد

استاذ امر اض النساء والتوليد كليه الطب جامعه المنصورة 1,استاذ مساعد تمريض النساء والتوليد كليه تمريض جامعه بورسعيل 2

مدرس تمريض الامومه والنساء والتوليد كليه تمريض جامعه بورسعيد3

\section{الخـلاصـة}

أن انخفاض ضغط الدم أثناء التخدير الثوكي لعملية الو لادة القيصرية لا يزال مشكلة سريرية مشتركة الخطورة للام والجنين . هدفت هذه الدراسة إلى تقييم تأثثير تقنية ضغط الساق السفلي للحد من انخفاض ضغط الدم الناجم عن التخدير الثوكى أثناء

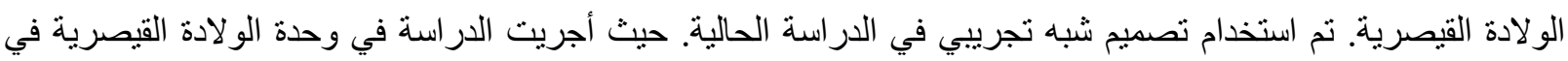
مستشفى جامعة المنصورة خلال الفترة من اكتوبر 2016 إلى مارس 2017. العينة: نم حساب عينة عشو ائية منتظمة مكونة من 220 سيده من النساء اللاتى خضعن لعملية ولادة قيصرية اختبارية باستخدام التخدير الثوكى وقد تم تقسيمهم الى مجمو عتين مجمو عة الدر اسة 110 سيده وقد تم اسبخدام تقنية ضغط الساق عن طريق استخدام جو ارب الدو الى ـ و المجموعه الثنانبة 110 سيدة وهى المجمو عه الضابطة و اللائى تلقين الرعاية التقليدية فى المستشفى ـ. وقد تم تعريف انخفاض ضغط الدم بأنه انخفاض في أي قياس فى الضغط الثريانى بأكثر من 20٪ من القياس الأساسى. الأدوات: تم استخدام ثلاثة أدوات في الدراسة الحالية لجمع البيانات اللازمة،1 استمارة مقابلة شخصية، 2سجل العلامات الحيوية للأمهات وعلامات سجل انخفاض ضغط 
الدم،3استمارة تقييم نتائج حديثي الولادة ومقياس أبجر. النتائج: كانت هناك فروق ذات دلالة إحصائية عالية بين مجموعه الدر اسة و المجمو عة الضابطة فيما يتعلق بالضغط الثرياني المتوسط ونسبة الحامضية فى دم الوليد.الاستتناج: اسبخدام جوارب الدوالى لضغط الساقين للنساء اثثاء الولادة القيصرية الاختبارية باستخدام التخدير الثوكى هو أكثر فعالية للحد من انخفاض ضغط الدم الناجم عن التخدير الثوكى أثناء الو لادة القيصرية. التوصيات: استخدام الجوارب لتحقيق ضغط الساق السفلى أثناء

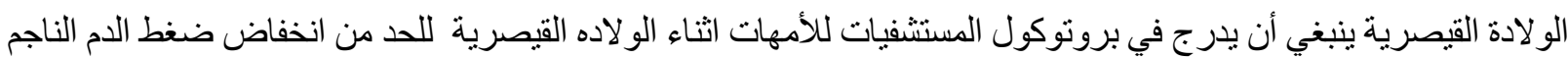
عن التخدير الثوكى اثناء الو لادة القيصرية. الكلمات المرشدة : تقنية ضغط الساق، انخفاض ضغط الدم، الو لادة القيصرية، انخفاض ضغط الدم الناتج عن التخدير الثوكى، الرعايه التمريضيه. 